\title{
SITOTOKSISITAS EKSTRAK ETANOLIK CURCUMA LONGA PADA SEL HeLa, STUDI IN VITRO
}

\author{
Chandra Kurniawan ${ }^{1}$, Jonathan Willy Siagian ${ }^{2}$, Suryani Hutomo ${ }^{3}$ \\ 1Fakultas Kedokteran Universitas Kristen Duta Wacana \\ 2Bagian Pathologi Anatomi, Fakultas Kedokteran Universitas Kristen Duta \\ Wacana \\ 3Bagian Mikrobiologi, Fakultas Kedokteran Universitas Kristen Duta Wacana \\ Korespondensi: suryanihutomo_drg@yahoo.com
}

\begin{abstract}
ABSTRAK
Kunyit (Curcuma longa) merupakan tanaman yang dapat tumbuh di daerah tropis dan sub tropis. Di Indonesia, kunyit menyebar secara merata di seluruh daerah. Kurkumin yang merupakan unsur utama kunyit. Penelitian terdahulu melaporkan bahwa kunyit memiliki kandungan kurkumin yang terbukti secara klinis memiliki efek antioksidan, anti-inflamasi, antiproliferasi, dan sitotoksik sehingga mampu menginduksi apoptosis pada sel-sel keganasan darah, payudara, colon, sel hati, dan ovarium, dengan sensitivitas setiap sel terhadap kurkumin yang berbeda-beda.

Tujuan penelitian ini adalah untuk mengkaji efek sitotoksik ekstrak etanol Curcuma longa yang didapatkan dari daerah Bantul pada sel HeLa. Sel HeLa merupakan cell line yang telah dikultur dan dikembangkan dari sel epitelial kanker leher rahim yang digunakan untuk berbagai kepentingan penelitian. Sel HeLa (2 x10 4 sel/well) dikultur dalam RPMI 1640 semalam sebelum stimulasi. Ekstrak etanol kunyit dengan berbagai konsentrasi ditambahkan pada kultur HeLa dan diinkubasi selama 24 jam dalam medium tanpa antibiotik. Analisis sitotoksisitas dilakukan dengan menggunakan metode $M T T$ assay. Doksorubisin $(0,5625 \mu \mathrm{g} / \mathrm{ml})$ digunakan sebagai kontrol positif.

Hasil penelitian menunjukkan bahwa ekstrak etanol Curcuma longa menyebabkan kematian sel sebesar 50\% (IC50) pada konsentrasi 184,5 $\mu \mathrm{g} / \mathrm{ml}$.

Disimpulkan bahwa ekstrak etanol Curcuma longa bersifat sitotosik pada sel HeLa, sehingga dapat dikembangkan agen kemopreventif.
\end{abstract}

Kata Kunci: ekstrak Curcuma longa, sel HeLa, sitotoksisitas. 


\title{
CYTOTOXICITY ETHANOL EXTRACT CURCUMA LONGA IN CELLS HELA, STUDY IN VITRO
}

\author{
Chandra Kurniawan ${ }^{1}$, Jonathan Willy Siagian², Suryani Hutomo ${ }^{3}$ \\ ${ }^{1}$ Medical Faculty of Duta Wacana Christian University \\ 2Pathology Anatomy, Medical Faculty of Duta Wacana Christian University \\ ${ }^{3}$ Microbiology Division, Medical Faculty of Duta Wacana Christian University \\ Corespondence: suryanihutomo_drg@yahoo.com
}

\begin{abstract}
Curcuma mostly found in areas with tropical and sub-tropical climate. In Indonesia, curcuma can be found in almost all regions and areas. Curcumin, which is curcuma's main constituent. Previous study reported that curcumin exhibit antioxidant, anti-inflamatory, anti-proliferation, and cytotoxicity effect, and inducing apoptoses in various cancer cells with different sensitivity.

The aim of this study is toevaluate the cytotoxicity of Curcuma longa extract against cervical cancer (HeLa) cell line in vitro. HeLa cells (2 $\times 104$ cells/well) were cultured in complete RPMI 1640 overnight before stimulation. Various concentration of Curcuma longa etanolic extract were added to the culture of HeLa cells and were incubated for 24 hours in antibiotic-free of culture medium. The cytotoxic activity was performed by using MTT assay. Doxorubicin $(0,5625 \mu \mathrm{g} / \mathrm{ml})$ was used as a positive control, and as negative control HeLa cell were grown without any treatment.

The results demonstrated that Curcuma longa extract exhibit cytotoxicity against HeLa cell line with IC50 of $184,5 \mu \mathrm{g} / \mathrm{ml}$. However, doxorubicin exhibit cytotoxicity against HeLa cell line with IC5O of $0,90 \mu \mathrm{g} / \mathrm{ml}$.

It means that Curcuma longa extract has lower cytotoxicity potential compared with doxorubicin.
\end{abstract}

Keywords: Curcuma longa extract, HeLa cells, apoptosis. 


\section{PENDAHULUAN}

Kunyit (Curcuma longa / tumeric) merupakan tanaman yang dapat tumbuh di daerah tropis dan sub tropis mulai dari ketinggian 2402000 meter di atas permukaan laut (dpl). Di Indonesia, kunyit menyebar secara merata di seluruh daerah. Tanaman ini tumbuh baik di tanah yang berpengairan baik dengan curah hujan sekitar $2.000-4.000$ mm/tahunnya. ${ }^{1}$ Kunyit termasuk tanaman obat, karena secara tradisional biasa digunakan untuk penyembuhan luka. Warna kuning kunyit berasal dari yang pigmen polifenol yang larut dalam lemak, yang dikenal dengan nama kurkuminoid. Kurkuminoid menyusun sekitar 2 9\% dari kandungan kunyit. Beberapa kandungan kurkuminoid yang bisa ditemukan pada kunyit adalah kurkumin, demethoxykurkumin dan bisdemethoxykurkumin. ${ }^{2}$ Kurkumin $[(1 \mathrm{E}, 6 \mathrm{E}) \quad-\quad 1,7-b i s$ (4-hydroxy-3methixyphenyl) hepta-1, 6-diene3,5dione] merupakan pigmen kuning utama yang dihasilkan dari ekstrak kunyit, yang diambil dari rhizoma tanaman kunyit (Curcuma longa). Kurkumin mempunyai efek antioksidan, antiviral dan antifungal serta aksi anti inflamasi melalui penghambatan beberapa molekul penting yang berperan dalam inflamasi. Efek anti-inflamasi kunyit merupakan kombinasi dari 3 mekanisme, yaitu menurunkan produksi histamin, meningkatkan produksi dan memperpanjang daya kerja cortisol yang dihasilkan oleh kelenjar adrenal yang memiliki efek anti-inflamasi serta meningkatkan sirkulasi darah, sehingga mampu mengeluarkan toksin-toksin (celular waste dan inflamatory compound) yang sering terperangkap di dalam sendi-sendi kecil. ${ }^{3}$

Beberapa penelitian melaporkan bahwa kurkumin mampu menghambat pertumbuhan beberapa tipe sel kanker. Mekanisme kurkumin menginduksi apoptosis diduga melalui penghambatan beberapa cellsignaling pathway. Target-targetnya antara lain transcription factor, oncogens, dan signaling protein. Kurkumin berperan dalam kontrol siklus sel dan stimulasi apoptosis melalui regulasi p16 dan p53. ${ }^{4}$ Tujuan penelitian ini adalah untuk mengkaji efek sitotoksik ekstrak etanol Curcuma longa pada sel HeLa.

\section{METODE PENELITIAN}

\section{Ekstraksi Curcuma longa}

Kunyit didapatkan dari daerah Bantul, Yogyakarta. Ekstraksi dilakukan dengan metode maserasi. Metode ini dilakukan dengan cara serbuk kunyit (simplisia) yang didapatkan dari rimpang kunyit usia 9 bulan, dimasukkan ke dalam wadah, setelah itu ditambahkan pelarut etanol dengan perbandingan 10 : 1 . Simplisia direndam selama 24 jam dengan melakukan pengadukan secara berkala, setelah itu dilakukan penampungan filtrat. Ampas yang didapatkan dari penyaringan kemudian direndam kembali dengan menggunakan etanol 96\%. Prosedur ini dilakukan sebanyak 3 kali. Setelah filtrat didapatkan maka dilakukan evaporasi dengan menggunakan evaporator hingga dihasilkan ekstrak semi padat etanol rimpang kunyit. Ekstrak kemudian keringkan dalam oven bersuhu $40^{\circ} \mathrm{C}$.

\section{Kultur Sel HeLa}

Sel HeLa ditumbuhkan dalam medium RPMI 1640 (Sigma-Aldrich, St Louis, MO, USA) yang disuplementasi dengan 10\% FBS, $100 \mathrm{IU} / \mathrm{ml}$ penisilin, $10 \mu \mathrm{g} / \mathrm{ml}$ streptomisin dalam suhu $37^{\circ} \mathrm{C}$ dengan kadar $\mathrm{CO}_{2} 5 \%$. Flask yang berisi sel diinkubasi untuk mendapatkan sejumlah sel yang dibutuhkan (konfluen). Sel HeLa dipanen dengan cara menambahkan 1-2 $\mathrm{ml}$ tripsin $0,25 \%$ ke dalam flask 
dan ditunggu beberapa saat. Sel HeLa kemudian dipindahkan ke conical tube dan ditambahkan medium RPMI hingga volume $10 \mathrm{ml}$ kemudian disentrifuge selama 5 menit dengan kecepatan 2000 rpm.

Supernatan kemudian dibuang, pelet diresuspensi dalam $1 \mathrm{ml}$ medium dan dihitung jumlahnya menggunakan bilik hitung. Suspensi sel dipindahkan pada 96 well-plate, ditambahkan sejumlah medium hingga memperoleh konsentrasi sel sebesar $2 \times 10^{4} \mathrm{sel} / 10 \mu \mathrm{l}$ dan siap digunakan.

\section{MTT Assay}

Suspensi sel kanker serviks (HeLa) sebanyak $100 \mu \mathrm{L}$ dengan kepadatan $2 \quad x \quad 10^{4}$ sel/100 $\mu \mathrm{L}$ didistribusikan ke dalam sumuransumuran pada 96-well plate dan diinkubasi 3 jam. Ke dalam sumuran dimasukkan $100 \mu \mathrm{L}$ larutan ekstrak kunyit dengan seri konsentrasi sebagai berikut: $12,5 \mu \mathrm{g} / \mathrm{ml}, 25$ $\mu \mathrm{g} / \mathrm{ml}, 50 \mu \mathrm{g} / \mathrm{ml}, 100 \mu \mathrm{g} / \mathrm{ml}$, dan 200 $\mu \mathrm{g} / \mathrm{ml}$, dengan 3 replikasi untuk masing masing kelompok. Sel diinkubasi overnight dalam inkubator dengan aliran 5\% CO2. Pada akhir inkubasi, media kultur dibuang lalu ditambahkan $10 \mu \mathrm{L}$ larutan MTT (5 $\mathrm{mg} / \mathrm{mL}$ PBS), dan medium diganti dengan $190 \mu \mathrm{L}$ medium RPMI 1640 komplit. Sel kemudian diinkubasi selama 3-4 jam. Reaksi MTT dihentikan dengan penambahan reagen stopper SDS $(100 \mu \mathrm{L})$. Microplate kemudian dibungkus dengan tissue dan diinkubasi selama 1 malam pada suhu kamar dan ruangan gelap. Sel yang hidup akan mereduksi MTT membentuk kristal formazan yang berwarna ungu. Hasil pengujian dibaca dengan ELISA reader pada panjang gelombang 595 nm.

\section{ANALISIS}

Untuk $\begin{gathered}\text { menentukan ada } \\ \text { hubungan antara }\end{gathered}$
tidaknya
konsentrasi ekstrak Curcuma longa
dan persentase kematian sel
digunakan regresi linear pada
Microsoft Excel guna mencari
persamaan kurva dosis respon dan
dilakukan perhitungan nilai IC50.

\section{HASIL PENELITIAN}

Hasil pengukuran nilai absorbansi supernatan menggunakan spektrofotometer (Bio-Rad Laboratories) mengindikasikan bahwa persentase kematian sel HeLa terus meningkat sebanding dengan kenaikan konsentrasi ekstrak yang diberikan. Kematian sel terbesar terdapat pada pemberian konsentrasi ekstrak $200 \mathrm{\mu g} / \mathrm{ml}$ yaitu sebesar $51,873 \%$ (Tabel 1).

Tabel 1. Persentase Kematian Sel HeLa

\begin{tabular}{cc}
\hline Konsentrasi ekstrak $(\boldsymbol{\mu g} / \mathbf{m} \mathbf{l})$ & Persentase kematian sel HeLa \\
\hline 200 & $51,873 \%$ \\
100 & $42,233 \%$ \\
50 & $34,940 \%$ \\
25 & $32,093 \%$ \\
12,5 & $31,194 \%$ \\
\hline
\end{tabular}

dibuat $\begin{gathered}\text { Berdasarkan hasil } \\ \text { grafik }\end{gathered}$ regresi atas, menggunakan Microsoft Excel, dan didapatkan persamaan $\mathrm{y}=0,0011 \mathrm{x}+$ 0,2912; dimana y merupakan persentase kematian sel HeLa, dan $\mathrm{x}$ merupakan konsentrasi ekstrak kunyit. Dari persamaan tersebut dilakukan perhitungan untuk mengetahui nilai IC50 ekstrak kunyit. Untuk perhitungan nilai IC50, maka harga y diganti menjadi 0,5 ; sehingga 
didapatkan nilai IC 50 sebesar 184,5 yang artinya ekstrak etanol kunyit menyebabkan kematian separuh jumlah sel HeLa pada konsentrasi
184,5 $\mu \mathrm{g} / \mathrm{ml}$. Hasil pada Tabel 1 dipresentasikan dalam bentuk grafik pada Gambar 1.

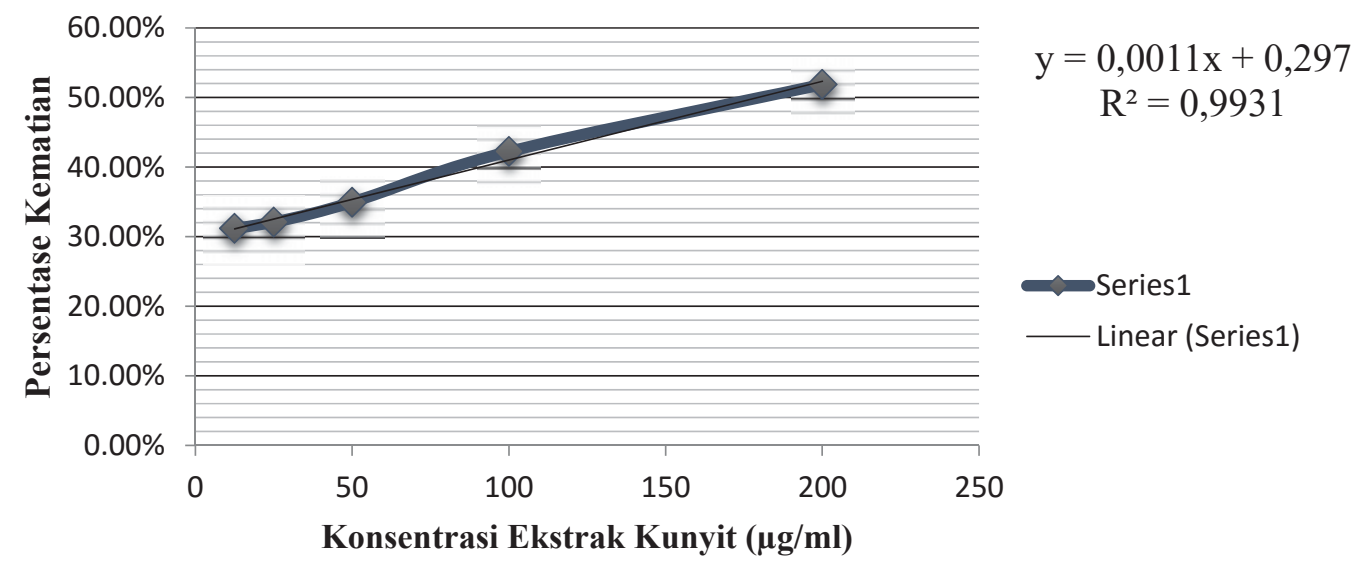

Gambar 1. grafik persentase kematian sel HeLa

\section{DISKUSI}

Hasil penelitian menunjukkan bahwa ekstrak kunyit dengan konsentrasi 184,5 $\mathrm{\mu g} / \mathrm{ml}$ mampu mematikan 50\% sel HeLa. Hasil ini sejalan dengan penelitian yang dilakukan oleh Anggraini (2007) yang menguji ekstrak rimpang Curcuma longa terhadap sel kanker payudara $\mathrm{T} 47 \mathrm{D}$, didapatkan harga IC50 $=100$ $\mu \mathrm{g} / \mathrm{ml}^{5} \quad$ Perbedaan sensitivitas terhadap paparan ekstrak yang seringkali dijumpai dalam penelitian bisa terjadi karena beberapa faktor, seperti kadar kurkumin yang terkandung di dalam ekstrak, jenis ekstrak, dan perbedaan cell line yang dipakai, sehingga setiap sel bisa memberikan respons yang berbedabeda terhadap paparan ekstrak. ${ }^{6}$

Kurkumin yang terkandung dalam ekstrak kunyit terbukti memiliki kemampuan untuk menginduksi penahanan siklus sel (cell cycle arrest) dan menginduksi apoptosis. Mekanisme kurkumin menginduksi apoptosis sangat bervariasi, dan diduga menginhibisi beberapa cell-signaling pathway.
Menurut Wilken (2011), efek antikanker curcumin melalui mekanisme sebagai berikut; pertama curcumin mensupresi aktivasi NF-ḱB melalui inihibisi akitivitas IḰKB sehingga mengakibatkan supresi gen yang berperan dalam tumorgenesis seperti TNF,COX-2, cyclin D1, c-myc, MMP-9 and interleukins. ${ }^{4}$ Kedua Curcumin berperan dalam pengontrolan siklus sel dan stimulasi apoptosis melalui regulasi p16 dan p53, dan ketiga curcumin merupakan modulator autophagy dan mempunyai efek inhibisi terhadap angiogenesis tumor dan inhibisi metastasis melalui supresi berbagai growth factor termasuk VEGF, COX-2, MMPs and ICAMs.

Studi yang dilakukan oleh Wang Y, tahun 1995 membuktikan bahwa kurkumin mampu menginduksi apoptosis sel tumor pada fase G2 melalui regulasi ekspresi p53 dan menginisiasi jalur apoptosis mitokondria melalui peningkatan ekspresi Bax dan pelepasan sitokrom $\mathrm{C}^{7}$. Kurcumin juga memiliki efek stimulasi jalur apoptosis ekstrinsik, yang dipicu dengan ikatan "death 
activator" seperti TNF alfa dan Fas Ligand yang masing-masing akan berikatan dengan reseptorreseptornya yang terdapat pada permukaan sel. Aktivasi reseptor terebut mengakibatkan aktivasi caspase-8 melalui receptor-attached FADD adapter molecule dan inisiasi kaskade caspase. Curcumin menunjukkan mempunyai efek menigkatkan level Fas dan FADD dan menginduksi apoptosis pada mouserat retinal ganglion cell.

Curcumin menyebabkan meningkatnya regulasi ekspresi famili Cip/Kip yang menginhibisi CDK (p21 Cip1/Waf1, p27 Kip1, p57 Kip2), sehingga menginhibisi pembentukan kompleks cyclin D1 dengan CDK4,6. Selain itu, curcumin juga mengurangi fosforilasi $\mathrm{Rb}$, dan mensupresi E2Fregulated gene. ${ }^{8}$

Ketidakteraturan kontrol siklus sel dapat mengakibatkan pembentukan sel tumor, dimana terjadi proliferasi dan pertumbuhan sel yang tidak terbatas. Contohnya pada overekspresi cyclin D1 terdapat pada banyak sel kanker, seperti pada keganasan darah. Curcumin berefek mensupresi cyclin D1 pada beberapa tipe kanker, seperti pada kanker kepala dan leher, kanker kolon, kanker serviks, kanker payudara, kanker pankreas, sebagai efek inhibisi dari aktivasi NF-ḱB. ${ }^{9}$

Penelitian lain yang dilakukan

oleh Mohammad et al., (2010) menggunakan ekstrak yang sama terhadap pada cell line kanker paru A549 selama 24 jam, menunjukkan nilai IC50 = 0,23 $\mu \mathrm{g} / \mathrm{ml}$. Dari beberapa hasil penelitian diatas, bisa terlihat bahwa nilai IC50 ekstrak Curcuma longa yang dipaparkan terhadap sel HeLa memerlukan konsentrasi yang jauh lebih tinggi bila dibandingkan dengan cell line yang lain. ${ }^{10}$ Studi lain oleh Maksum (2010) yang mengunakan ekstrak Curcuma zedoaria (temu putih) pada sel HeLa mendapatkan nilai IC50 $=58,9$ $\mu \mathrm{g} / \mathrm{ml} .^{11}$ Jika dibandingkan dengan harga IC50 Curcuma longa, maka efek sitotoksik ekstrak Curcuma zedoaria lebih besar jika dipaparkan pada sel HeLa.

National Cancer Institute (NCI) menetapkan kriteria bagi ekstrak bahan alam yang akan dikembangkan sebagai obat antikanker. Ekstrak bahan alam dengan nilai IC50 < 30 $\mu \mathrm{g} / \mathrm{ml}$ dianggap mempunyai efek sitotoksisitas yang potensial, dan dilanjutkan untuk diuji lebih lanjut dengan cell line yang lain secara in vitro. ${ }^{12}$ Berdasarkan kriteria tersebut, ekstrak kunyit (Curcuma longa) tidak direkomendasikan untuk diteliti lebih lanjut sebagai obat anti kanker, tetapi bisa dikembangkan sebagai agen kemoprevensi. Studi epidemiologi oleh Mohandas (1999) menunjukkan bahwa angka kejadian kanker kolon di India yang rendah dihubungkan dengan aktivitas kemoprevensi dan antioksidan curcumin yang sangat banyak dikonsumsi sebagai bumbu pada makanan.

\section{KESIMPULAN}

Ekstrak etanol kunyit bersifat
toksik pada sel HeLa dan menyebabkan kematian sebesar separuh dari jumlah sel HeLa pada konsentrasi 184,5 $\mu \mathrm{g} / \mathrm{ml}$.

\section{DAFTAR PUSTAKA}

1. Syukur, C dan Hernani. Budi Daya Tanaman Obat Komersial. Jakarta : Penebar Swadaya. 2001 Hlm :76-77.

2. Nayak, P.L. Curcumin : a wonder anticancer drug. Int $J$ Phram Biomed, 2012 : 60-69.

3. Akram M. Curcuma longa and curcumin. J Biol. - Plant Biol., 2010 (55):65- 70.

4. Wilken Reason. Curcumin: A review of anti-cancer properties and therapeutic activity in head and neck squamous cell carcinoma. Molecular cancer. 
$2011 . \quad$ (diakses dari: http://www.molecularcancer.com/content/10/1/12).

5. Anggraini, Polis Novita. Aktivitas Campuran Ekstrak Etanol Herba Sambiloto dan Rimpang Kunyit terhadap Sel Kanker Payudara Manusia T47D in vitro dengan Metode MTT. Skripsi Universitas Airlangga, Surabaya 2007.

6. Prayong P, Barusrux S, Weerapreeyakul N. Cytotoxic activity screening of some indigenous Thai plants. Fitoterapia, 2008. 79:598-601.

7. Wang Y, Okan I, Szekely L, Klein G, Wiman KG. (1995) Bcl-2 inhibits wild-type p53- triggered apoptosis but not G1 cell cycle arrest and transactivation of WAF1 and Bax. Cell Growth Differ, 6:1071-1075.

8. Mukhopadhyay A, Banerjee S, Stafford LJ, Xia C, Liu M, Aggarwal BB. Curcumin-induced suppression of cell proliferation correlates with down-regulation of cyclin D1 expression and CDK4mediated retinoblastoma protein phosphorylation. Cell Cycle, 2007. 6:2953-2961.

9. Liu Q, Loo WT, Sze SC, Tong Y. Curcumin inhibits cell proliferation of MDA-MB-231 and BT-483 breast cancer cells mediated by downregulation of NFkappaB, cyclinD and MMP-1 transcription. Phytomedicine, 2009. 16:916-922.

10. Maksum Radji, et al. Uji Sitotoksisitas Buah Merah, Mahkota Dewa, dan Temu Putih terhadap sel kanker serviks. Jurnal Farmasi Indonesia Vol. 5 No.1 Januari 2010 hal. 41-47.

11. Itharat A., B. Ooraikul. Research on Thai medicinal plants for cancer treatment. Advances in Medicinal Plant Research. 2007.

12. Mohandas KM, Desai DC. Epidemiology of digestive tract cancers in India : Large and small bowel. Indian $J$ Gastroenterol, 1999. 18:118-121. 
